Dikirim: 10 Oktober 2016 Diterbitkan: 1 Juli 2017

\section{Beban biaya penyakit demam berdarah dengue di rumah sakit dan puskesmas}

\section{Cost burden of dengue hemorrhagic fever in hospitals and public health centers}

\section{Evitrisna Warni Sihite ${ }^{1}$, Yodi Mahendradata ${ }^{2}$, Tri Baskoro ${ }^{3}$}

\begin{abstract}
Purpose: This study aimed to determine the cost caused by dengue fever disease based on the perspectives of the patients/family in hospitals and primary health centers in Banjarnegara district in 2016. Methods: This study used a descriptive design with prospective survey. Secondary data were obtained from hospitals and primary health centers, and primary data was collected by interviews. The data were processed by MS Excel software and analyzed by using STATA software version 12. Results: Subjects in this study was 57 respondents. The direct cost was 207.290.500 IDR (mean: 3.636.676 IDR). Indirect cost was 68.0169.900 IDR (mean: 1.193.300 IDR). Cost of dengue fever disease was 275.307.500 IDR (mean: 4.829.955 IDR). Cost of dengue fever disease was higher in males, age group more than 15 years, worker group, with disease duration more than 7 days, no insurance ownership, no insurance use, health care facility use, private practice and hospital, more than 2 visits, and travel time more than 15 minutes. The analysis showed correlations with age $(p=0.0209)$, employment status ( $p=$ $0.0389)$, the ownership of health insurance $(p=0.0022)$, and the use of health insurance $(p=0.0003)$. Conclusion: Dengue fever disease cost was 275.307.500 IDR, where $75.29 \%$ was direct costs and $24.71 \%$ indirect costs. There was no increase in the active participation of each sector nor a clear division of roles for each sector so that control of dengue can be properly directed with more budget support for the prevention and control of dengue.
\end{abstract}

Keywords: cost; dengue hemorrhagic fever; primary health center; hospital

\footnotetext{
${ }^{1}$ Departemen Biostatistik, Epidemiologi dan Kesehatan Populasi, Fakultas Kedokteran, Universitas Gadjah Mada (Email: evitrisnawarni@ymail.com)

${ }^{2}$ Departemen Kebijakan dan Manajemen Kesehatan, Fakultas Kedokteran, Universitas Gadjah Mada

${ }^{3}$ Departemen Parasitologi, Fakultas Kedokteran, Universitas Gadjah Mada
} 


\section{PENDAHULUAN}

Dalam lima puluh tahun terakhir, insiden demam berdarah dengue (DBD) mengalami peningkatan 30 kali lipat (1). Diperkirakan sebanyak 3,97 juta orang berada di 128 negara endemis (2), 390 juta infeksi dengue terjadi setiap tahun dan $70 \%$ orang yang terkena DBD berada di wilayah Asia (3). Data dar world health organization (WHO) menunjukkan bahwa Indonesia sebagai peringkat pertama di Asia Tenggara dan peringkat kedua dunia setelah Brazil pada tahun 2004-2010 untuk jumlah rata-rata kasus DBD (1). Pada umumnya penyakit DBD meningkat karena faktor lingkungan dan praktik pencegahan tidak konsisten, urbanisasi, mobilisasi, peningkatan jumlah penduduk, pengolahan sampah buruk, infrastruktur kesehatan yang tidak memadai, dan kekurangan sumber daya untuk mengendalikan vektor $(4,5)$.

Pada tahun 2014, incidence rate DBD di provinsi Jawa Tengah sebesar 36,2/100.000 penduduk, angka ini menurun dibandingkan tahun 2013 (41,21/100.000 penduduk) (6). Kabupaten Banjarnegara merupakan salah satu kabupaten di Provinsi Jawa Tengah, dalam 5 tahun terakhir terus menerus mengalami peningkatan kasus DBD. Pada tahun 2011, jumlah penderita DBD sebanyak 100 kasus (IR 10,1/100.000 penduduk), tahun 2012 sebanyak 129 kasus (IR 13/100.000 penduduk), tahun 2013 sebanyak 134 kasus (IR 13,5/100.000 penduduk), tahun 2014 sebanyak 141 kasus (IR 14,43/100.000 penduduk), dan tahun 2015 sebanyak 197 orang (IR 17/100.000) (7,8,9). Di awal tahun 2016, Kabupaten Banjarnegara telah mengalami kejadian luar biasa (KLB) DBD dengan peningkatan jumlah kasus DBD sebanyak 230 kasus hingga minggu pertama bulan April 2016 (10).

Kasus DBD di puskesmas non inap di kabupaten Banjarnegara paling banyak ditemukan di puskesmas Banjarnegara I dengan jumlah kasus tahun 2014 sebanyak 24 (IR 71,93/100.000 penduduk), tahun 2015 sebanyak 17 kasus (IR 52,37/100.000 penduduk), dan meningkat secara drastis hingga bulan April 2016 sebanyak 36 kasus (IR 110,89/100.000 penduduk). Sedangkan untuk pukesmas rawat inap, kasus DBD paling banyak ditemukan di puskesmas Wanadadi I dengan jumlah kasus tahun 2014 sebanyak 30 kasus (IR 14,88/100.000 penduduk), tahun 2015 sebanyak 11 kasus (IR 28,49/100.000 penduduk), dan bulan April 2016 sebanyak 11 kasus (IR 52,23/100.000 penduduk).

Semua pasien DBD di kabupaten Banjarnegara yang berobat pada fasilitas pelayanan primer seperti puskesmas dan praktik swasta, sebagian besar dirujuk ke rumah sakit untuk mendapatkan perawatan lanjutan. RSUD Hj. Anna Lasmanah adalah rumah sakit yang paling banyak mendapat rujukan kasus DBD di kabupaten Banjarnegara. Jumlah kasus DBD yang dirawat, baik rawat jalan dan rawat inap tahun 2012 sebanyak 37 kasus, tahun 2013 sebanyak 66 kasus, tahun 2014 sebanyak 83 kasus, tahun 2015 sebanyak 85 kasus (11).

Peningkatan kasus DBD merupakan ancaman besar untuk kesehatan masyarakat dan ekonomi yang besar (12). Dampak dari DBD diukur dari biaya langsung, seperti alokasi dana yang tidak direncanakan untuk menanggulangi KLB DBD, biaya perawatan medis, seperti biaya rawat inap dan rawat jalan, hilangnya hari kerja produktif karena sakit atau untuk merawat anggota keluarga yang sakit, dan biaya tidak langsung, seperti peningkatan pengeluaran rumah tangga untuk membeli obat nyamuk dan obat-obatan, penurunan pendapatan rumah tangga karena kehilangan hari kerja (13).

Penelitian di Asia Tenggara menunjukkan bahwa total beban ekonomi tahunan untuk penyakit DBD sebesar US \$ 950 juta dan Indonesia adalah negara dengan beban ekonomi tertinggi, yaitu sebesar US \$ 323.163 atau $34 \%$ dari total keseluruhan biaya (14). Hasil penelitian lainnya yang dilakukan di RSUD Tarakan provinsi DKI Jakarta menunjukkan total biaya yang dikeluarkan selama menderita penyakit DBD Rp. 892.067 (15). Penelitian di Brazil menunjukkan biaya medis langsung berhubungan dengan dengue sama dengan 2,5\% dari produk domestik publik per kapita sebesar US \$210,084 (16).

Penelitian di India menunjukkan total biaya medis langsung rata-rata dalam setahun sebesar US $\$ 548$ juta dengan $82 \%$ biaya untuk pasien rawat inap dan $18 \%$ untuk pasien rawat jalan. Beban ekonomi sekitar US \$111 juta atau \$ 0.88 per kapita termasuk biaya non medis dan biaya tidak langsung (17). Penelitian beban ekonomi dan beban biaya di Meksiko menunjukkan beban ekonomi akibat penyakit DBD sebesar US \$ 170 juta atau US $\$ 1,56$ per kapita (18).

Penelitian ini dilaksanakan berdasarkan jumlah kasus DBD yang terus mengalami peningkatan, dengan tujuan mengetahui biaya yang disebabkan penyakit DBD berdasarkan perspektif pasien/keluarga di rumah sakit dan puskesmas kabupaten Banjarnegara tahun 2016.

\section{METODE}

Jenis penelitian ini adalah deskriptif dengan desain survei prospektif yang bertujuan untuk menghitung estimasi biaya kesakitan kasus DBD menurut perspektif 
pasien. Penelitian ini menganalisis secara deskriptif besar biaya yang dikeluarkan pada setiap kasus DBD di rumah sakit dan puskesmas, untuk mendeskripsikan besarnya biaya langsung dan biaya tidak langsung kasus DBD. Populasi penelitian ini adalah pasien yang didiagnosa menderita penyakit DBD di puskesmas Wanadadi I, puskesmas Banjarnegara I, RSUD Hj Anna Lasmanah kabupaten Banjarnegara bulan Juni-Agustus tahun 2016 dengan bukti hasil konfirmasi laboratorium.

Data primer diperoleh dengan wawancara pada penderita/orang tua (penderita $<15$ tahun), sedangkan data sekunder diperoleh dari Puskesmas dan RSUD, berupa data jenis layanan kesehatan dan tarif biaya. Pengumpulan data dilakukan dengan menggunakan kuesioner. Data ditabulasi dengan menggunakan Microssoft Excel dan dianalisis dengan program Stata versi 12.

Data dianalisis secara deskriptif. Data memiliki sebaran tidak normal sehingga dianalisa menggunakan perhitungan besar biaya, nilai median, dan quartil yang disajikan dalam bentuk tabel dan narasi. Sebagai tambahan analisis dilakuakan uji bivariat mengetahui variabel paling memengaruhi terhadap biaya penyakit DBD. Uji bivariat dilakukan dengan menggunakan uji Mann-Whitney dan uji Kruskal Wallis.

\section{HASIL}

Penderita DBD, 39 orang $(68,42 \%)$ berjenis kelamin laki-laki, 45 orang (78,95\%) pada kelompok umur >15 tahun, 17 orang (29,82\%), berpendidikan sekolah menengah atas dan akademi/perguruan tinggi, 14 orang $(24,56 \%)$ berstatus pelajar, 55 orang (96,49\%) lama sakit $>7$ hari, $77,19 \%$ memiliki jaminan kesehatan, 71,93\% menggunakan jaminan kesehatan, $52,63 \%$ mengunjungi praktik swasta dan rumah sakit umum daerah, 42,11\% mengunjungi fasilitas layanan kesehatan sebanyak 3 kali kunjungan, dan 59,65\% membutuhkan waktu tempuh perjalanan ke fasilitas layanan kesehatan $\leq 15$ menit. Biaya langsung penyakit DBD sebesar Rp. 207.290.500. Rata-rata biaya langsung penyakit DBD adalah Rp. 3.636.676. Nilai median sebesar Rp. 2.194.450, dan range antar kuartil (IQR) sebesar Rp. 4.216.150 (Q3-Q1).
Tabel 1. Ciri responden

\begin{tabular}{|c|c|}
\hline Variabel & $\%$ \\
\hline \multicolumn{2}{|l|}{ Jenis kelamin } \\
\hline Perempuan & 31,58 \\
\hline Laki-laki & 68,42 \\
\hline \multicolumn{2}{|l|}{ Umur } \\
\hline$\leq 15$ tahun & 21,05 \\
\hline$>15$ tahun & 78,95 \\
\hline \multicolumn{2}{|l|}{ Pendidikan } \\
\hline Belum Sekolah & 7,02 \\
\hline SD & 15,79 \\
\hline SMP & 17,54 \\
\hline SMA & 29,82 \\
\hline Akademi/PT & 29,82 \\
\hline \multicolumn{2}{|l|}{ Jenis pekerjaan } \\
\hline PNS & 21,05 \\
\hline Pegawai BUMN & 1,75 \\
\hline Pegawai Swasta & 3,51 \\
\hline Pegawai Honorer & 3,51 \\
\hline Wiraswasta & 14,04 \\
\hline Petani & 7,07 \\
\hline Sopir & 1,75 \\
\hline Buruh & 5,26 \\
\hline IRT & 3,51 \\
\hline Pelajar & 24,56 \\
\hline Pengangguran & 7,02 \\
\hline Balita & 7,02 \\
\hline \multicolumn{2}{|l|}{ Lama sakit } \\
\hline$\leq 7$ hari & 3,51 \\
\hline$>7$ hari & 96,49 \\
\hline \multicolumn{2}{|c|}{ Status kepemilikan jaminan kesehatan } \\
\hline Tidak & 22,81 \\
\hline Ya & 77,19 \\
\hline \multicolumn{2}{|c|}{ Penggunaan jaminan kesehatan } \\
\hline Tidak & 28,07 \\
\hline Ya & 71,93 \\
\hline \multicolumn{2}{|c|}{ Fasilitas layanan kesehatan } \\
\hline RSUD & 14,04 \\
\hline PKM dan RSUD & 21,05 \\
\hline PS dan RSUD & 52,63 \\
\hline PS, PKM dan RSUD & 12,28 \\
\hline \multicolumn{2}{|l|}{ Frekuensi kunjungan } \\
\hline$\leq 2$ kali kunjungan & 33,33 \\
\hline$>2$ kali kunjungan & 66,67 \\
\hline \multicolumn{2}{|l|}{ Waktu tempuh } \\
\hline$\leq 15$ menit & 59,65 \\
\hline$>15$ menit & 40,35 \\
\hline
\end{tabular}

Biaya tidak langsung atau biaya pendapatan yang hilang akibat penyakit DBD adalah Rp. 68.016.900. Besar pendapatan yang hilang pada penderita DBD 2 (dua) kali lipat lebih besar dibandingkan pendapatan yang hilang pada keluarga penderita. Nilai median sebesar Rp. 775.000 dan nilai IQR Rp. 1.161.200.

Biaya kesakitan penyakit DBD Rp. 275.307.500, dimana 75,29\% merupakan biaya langsung, dan 24,71\% merupakan biaya tidak langsung. Biaya kesakitan penyakit DBD per kasus sebesar Rp. 4.829.955. Nilai median sebesar Rp. 3.739.050, nilai IQR Rp. 5.046.950. 
Tabel 2. Biaya langsung dan pendapatan yang hilang

\begin{tabular}{|c|c|c|c|c|c|c|}
\hline \multirow{2}{*}{ Kategori } & \multicolumn{2}{|c|}{ Total } & \multirow{2}{*}{$\begin{array}{c}\text { Rata-rata } \\
\text { Rp. }\end{array}$} & \multirow{2}{*}{$\begin{array}{c}\text { Median } \\
\text { Rp. }\end{array}$} & \multirow{2}{*}{$\begin{array}{l}\text { Q1 } \\
\text { Rp. }\end{array}$} & \multirow{2}{*}{$\begin{array}{l}\text { Q3 } \\
\text { Rp. }\end{array}$} \\
\hline & Rp. & $\%$ & & & & \\
\hline \multicolumn{7}{|l|}{ Biaya langsung } \\
\hline Layanan kesehatan & 137.944 .300 & 66,55 & 2.420 .076 & 1.328 .350 & 100.000 & 3.840 .450 \\
\hline Transportasi & 15.525 .000 & 7,49 & 272.368 & 250.000 & 162.000 & 330.000 \\
\hline Makan dan minum & 33.366 .400 & 16,10 & 585.375 & 548.500 & 460.500 & 680.000 \\
\hline Lain-lain & 20.454 .800 & 9,87 & 358.856 & 60.000 & 25.000 & 116.500 \\
\hline \multicolumn{7}{|c|}{ Pendapatan yang hilang } \\
\hline Penderita DBD & 45.680 .200 & 67,16 & 801.407 & 522.500 & 42.200 & 1.200 .000 \\
\hline Keluarga & 22.336.700 & 32,84 & 391.871 & 300.000 & 175.000 & 494.000 \\
\hline
\end{tabular}

Tabel 3. Biaya kesakitan

\begin{tabular}{|c|c|c|}
\hline Variabel & $\%$ & P-Value \\
\hline \multicolumn{3}{|l|}{ Jenis kelamin } \\
\hline Perempuan & 31,58 & 0,6065 \\
\hline Laki-laki & 68,42 & \\
\hline \multicolumn{3}{|l|}{ Umur } \\
\hline$\leq 15$ tahun & 21,05 & $0,0209 *$ \\
\hline$>15$ tahun & 78,95 & \\
\hline \multicolumn{3}{|l|}{ Status pekerjaan } \\
\hline Tidak bekerja & 12,28 & $0,0389 *$ \\
\hline Bekerja & 59,65 & \\
\hline \multicolumn{3}{|l|}{ Lama sakit } \\
\hline$\leq 7$ hari & 3,51 & 0,2246 \\
\hline$>7$ hari & 96,49 & \\
\hline \multicolumn{3}{|c|}{ Kepemilikan jaminan kesehatan } \\
\hline Tidak & 22,81 & $0,0022^{*}$ \\
\hline Ya & 77,19 & \\
\hline \multicolumn{3}{|c|}{ Penggunaan jaminan kesehatan } \\
\hline Tidak & 28,07 & $0,0003^{*}$ \\
\hline $\mathrm{Ya}$ & 71,93 & \\
\hline \multicolumn{3}{|c|}{ Fasilitas layanan kesehatan } \\
\hline RSUD & 14,04 & 0,1649 \\
\hline PKM dan RSUD & 21,05 & \\
\hline PS dan RSUD & 52,63 & \\
\hline PS, PKM dan RSUD & 12,28 & \\
\hline \multicolumn{3}{|l|}{ Frekuensi kunjungan } \\
\hline$\leq 2$ kali kunjungan & 33,33 & 0,6598 \\
\hline > 2 kali kunjungan & 66,67 & \\
\hline \multicolumn{3}{|l|}{ Waktu tempuh } \\
\hline$\leq 15$ menit & 59,65 & 0,8325 \\
\hline$>15$ menit & 40,35 & \\
\hline
\end{tabular}

\section{BAHASAN}

Pada awal tahun 2016, kabupaten Banjarnegara dinyatakan berada dalam kondisi status kejadian luar biasa DBD. Meskipun sudah tidak dalam status KLB, kasus DBD tetap ada. Kondisi tersebut mempunyai dampak pada biaya kesakitan penyakit DBD yang harus ditanggung oleh pasien/keluarga. Penelitian bertujuan untuk mengetahui biaya yang disebabkan penyakit DBD berdasarkan perspektif pasien/keluarga di rumah sakit dan puskesmas kabupaten Banjarnegara tahun 2016

Total biaya langsung Rp. 207.290.500, dengan rata-rata Rp. 3.636.675. Komponen biaya langsung terdiri atas biaya layanan kesehatan Rp. 137.944.350, biaya transportasi Rp. 15.525.000, biaya makan dan minum Rp. 33.336.400, dan biaya lain Rp. 20.454.800. Penelitian ini sejalan dengan studi dari Undurraga, yang menyatakan bahwa biaya medis lebih tinggi dibandingkan dengan non medis pada pasien rawat inap dan rawat jalan (18).

Nilai median sebesar Rp. 2.194.450 dan nilai simpangan kuartil (IQR) sebesar Rp. 4.331.050. Berdasarkan nilai tersebut diketahui bahwa median lebih rendah dibandingkan dengan rata-rata dan IQR. Hal menunjukkan adanya biaya langsung yang sangat besar pada beberapa penderita. Besar biaya langsung disebabkan penderita DBD merupakan pasien umum, sehingga semua biaya pengobatan di fasilitas layanan kesehatan dibayar sendiri oleh penderita.

Rata-rata waktu produktivitas yang hilang pada penderita sebagai berikut pekerja 12 hari, anak sekolah 9 hari, dan ibu rumah tangga 9 hari. Sedangkan pada keluarga penderita pekerja 8 hari dan ibu rumah tangga 8 hari. Penelitian ini sejalan dengan penelitian Halasa, yang menyatakan rata-rata absensi kerja dan sekolah masing-masing 8,3 dan 6,5 hari (12).

Pada penderita DBD ditemukan bahwa 92,37\% pendapatan yang hilang ditanggung oleh penderita pekerja. Apabila keluarga pekerja yang menderita DBD, maka pendapatan yang hilang $61,08 \%$. Total biaya pendapatan hilang sebesar Rp. 68.016.900, dengan rata-rata Rp. 1.193 .300 atau setara dengan 94,33\% dari upah minimum kabupaten Banjarnegara. Nilai median sebesar Rp. 775.000 dan IQR Rp. 1.161.200. Median lebih rendah dibandingkan dengan rata-rata dan IQR. Hal ini menunjukkan adanya biaya tidak langsung cukup besar namun hanya terdapat pada beberapa penderita. Hasil ini sesuai dengan penelitian Gao yang menemukan besar opportunity cost pekerja lebih besar dibandingkan dengan yang bukan pekerja (19).

Biaya kesakitan penyakit DBD sebesar Rp. 275.307 .450 yang terdiri atas $75,29 \%$ biaya langsung dan $24,71 \%$ biaya tidak langsung. Hasil ini seperti penelitian Suaya, Martelli, Halasa, yang menyimpulkan bahwa biaya langsung merupakan biaya yang paling besar dari total biaya untuk kasus DBD $(20,13,6)$. Besar rata-rata biaya kesakitan penyakit DBD untuk setiap kasus DBD sebesar Rp. 4.830.000, dengan median Rp. 
3.739.050, IQR Rp. 5.046.95. Angka ini menunjukkan adanya biaya kesekitan yang sangat besar namun hanya pada beberapa penderita dan memperlihatkan adanya range yang lebar antara biaya kesakitan minimal dan maksimal.

Penelitian menunjukkan bahwa 68,24\% penderita DBD pada laki-laki. Hasil ini sejalan dengan penelitian Triana dan Allosomba. Tingginya angka kejadian pada laki-laki disebabkan oleh aktivitas dan mobilitas di luar rumah yang lebih tinggi dibandingkan dengan pada perempuan $(21,15)$. Biaya kesakitan penyakit DBD pada penderita laki-laki lebih besar dibandingkan penderita perempuan, namun secara statistik tidak terdapat perbedaan yang signifikan.

Sebanyak 78,94\% penderita DBD berada pada kelompok umur > 15 tahun. Hasil ini sejalan dengan penelitian Martelli dan Vieira, yang menjelaskan bahwa 53,5\% kasus DBD pada kelompok usia 15 hingga 60 tahun $(10,22)$. Biaya kesakitan DBD kelompok umur $\leq 15$ tahun lebih rendah daripada penderita DBD yang berusia > 15 tahun dan secara statistik terdapat perbedaan yang signifikan. Hasil ini sejalan dengan penelitian Vieira, yang menunjukkan bahwa nilai median pada kelompok umur 15 sampai dengan 60 tahun lebih besar daripada kelompok umur $\leq 15$ tahun (16). Hal ini juga sejalan dengan penelitian Halasa yang menyatakan bahwa dari semua biaya penyakit DBD, anak-anak menyumbang 30\% dari total biaya penyakit DBD, sedangkan orang dewasa menyumbang $70 \%$ dari total biaya (12).

Sebanyak 57,89\% penderita DBD adalah pekerja. Hasil ini berbeda dengan penelitian Magdalena, yang menemukan 78,26\% penderita DBD tidak bekerja. Hal ini disebabkan karena kelompok yang tidak bekerja memiliki waktu lebih banyak berada di dalam rumah ataupun di sekolah, dan kebiasaan nyamuk betina yang menggigit pada siang hari, yaitu pukul 09.00-10.00 dan 16.00-17.00, yang merupakan saat-saat kelompok tidak bekerja lebih banyak berada di dalam ruangan (22). Namun jika dilihat berdasarkan jenis pekerjaan, penyakit DBD lebih banyak pada anak sekolah yaitu sebanyak 14 orang, hasil ini sejalan dengan penelitian Allosomba (15).

Sebanyak 96,49\% penderita DBD mengalami lama sakit $>7$ hari. Hasil ini sejalan dengan penelitian Shepard yang menyatakan bahwa durasi pasien DBD sejak dari muncul gejala hingga sembuh total adalah $8,7 \pm 13,0$ hari untuk pasien rawat jalan dan 11,4 $\pm 20,6$ hari untuk pasien rawat inap (17). Penelitian Undurraga menyatakan bahwa durasi episode demam berdarah pada pasien yang dirawat sebesar 12,9 hari (18). Biaya kesakitan penyakit DBD pada penderita dengan lama sakit $>7$ hari lebih besar daripada lama sakit $\leq 7$ hari. Pada umumnya besar biaya perawatan baik rawat jalan dan rawat inap berbanding lurus dengan lama sakit penderita. Seperti hasil penelitian Campenhausen, yang menyatakan biaya meningkat sejalan dengan tingkat keparahan penyakit (23).

Sebanyak 77,19\% penderita DBD memiliki jaminan kesehatan. Angka ini lebih tinggi jika dibandingakan dengan penelitian Martias yang menyimpulkan secara nasional 57\% masyarakat mempunyai kepemilikan jaminan kesehatan (24). Nilai median biaya kesakitan kasus penyakit DBD lebih besar pada penderita yang tidak memiliki jaminan kesehatan, namum IQR lebih besar pada penderita dengan jaminan kesehatan disebabkan adanya perpindahan kelas rawatan ke kelas rawatan yang lebih tinggi sehingga penderita mengeluarkan biaya untuk membayar selisih tarif rawatan.

Sebanyak 93,18\% penderita DBD menggunakan jaminan kesehatan pada saat mencari pengobatan di fasilitas kesehatan. Hasil penelitian ini sejalan dengan penelitian Radja, yang menemukan 24,6\% pemilik asuransi di Indonesia Timur tidak menggunakan jaminan kesehatan ketika menjalani rawat inap (25). Biaya kesakitan penyakit DBD pada penderita DBD yang tidak menggunakan jaminan kesehatan lebih besar daripada yang menggunakan jaminan kesehatan.

Sebanyak 52,63\% mengunjungi fasilitas kesehatan praktik swasta dan RSUD. Tingginya penggunaan praktik swasta berkaitan dengan jarak, penderita akan mencari pengobatan terlebih dahulu kepada dokter, bidan, dan mantri terdekat dengan tempat tinggal. Hasil ini sejalan dengan penelitian Praptiningsih (26). Biaya kesakitan penyakit DBD pada penderita DBD yang mengunjungi fasilitas kesehatan kelompok praktik swasta dan RSUD lebih tinggi daripada yang mengunjungi kelompok fasilitas kesehatan lainnya.

Sebanyak 66,67\% penderita DBD mengunjungi fasilitas layanan kesehatan > 2 kali kunjungan. Hasil ini sejalan dengan penelitian Undurraga yang menyatakan bahwa penderita DBD pada orang dewasa akan melakukan kunjungan rawat jalan sebanyak 2,4 kali sebelum dirawat inap di rumah sakit, sedangkan penderita DBD pada anak-anak memiliki rata-rata kunjungan 3,7 kali rawat jalan sebelum di rawat inap (18). Biaya kesakitan penyakit DBD pada penderita DBD yang mengunjungi fasilitas layanan kesehatan $>2 \mathrm{kali}$ kunjungan lebih tinggi daripada penderita yang mengunjungi $\leq 2$ kali kunjungan. Kunjungan yang berulang ke fasilitas kesehatan akan meningkatkan pengeluaran biaya terutama kunjungan ke fasilitas 
pelayanan lanjutan atau fasilitas layanan kesehatan tingkat dua (27).

Biaya yang dibutuhkan untuk mengakses fasilitas layanan kesehatan yang membutuhkan waktu tempuh $>15$ menit lebih tinggi dibandingkan waktu tempuh $\leq$ 15 menit. Jarak dan waktu tempuh memiliki dampak signifikan pemanfaatan fasilitas layanan kesehatan (28). Pendapatan penderita/keluarga sulit untuk diukur dengan tepat. Penderita dan keluarga merahasiakan penghasilan yang diterima.

\section{SIMPULAN}

Biaya langsung biaya kesakitan penyakit DBD sebesar Rp. 207.290.500, biaya tidak langsung Rp. 68.016.900. Biaya kesakitan penyakit DBD adalah Rp. 275.307.500, dengan 75,29\% dari total biaya kesakitan kasus penyakit DBD merupakan biaya langsung dan $24,71 \%$ biaya tidak langsung. Biaya kesakitan kasus penyakit DBD per kasus adalah sebesar Rp. 4.829.955. Hasil variasi biaya kesakitan DBD ditemukan bahwa laki-laki, kelompok >15 tahun, pada kelompok pekerja, dengan lama sakit $>7$ hari, tidak memiliki jaminan kesehatan dan penderita yang tidak menggunakan jaminan kesehatan, praktik swasta dan RSUD, pada $>2$ kali kunjungan, dan pada penderita dengan waktu tempuh >15 menit mempunyai biaya kesakitan DBD yang lebih besar dan biaya yang paling memengaruhi terhadap besarnya pengeluaran adalah umur dan status pekerjaan, kepemilikan jaminan kesehatan dan penggunaan jaminan kesehatan.

\section{Abstrak}

Tujuan: Penelitian ini bertujuan untuk mengetahui biaya yang disebabkan penyakit DBD berdasarkan perspektif pasien/keluarga di rumah sakit dan puskesmas kabupaten Banjarnegara. Metode: Jenis penelitian yaitu deskriptif dengan desain survei prospektif. Data sekunder diperoleh dari puskesmas dan rumah sakit dan data primer melalui wawancara. Data diolah dengan software MS Excel dan dianalisis menggunakan software STATA versi 12 . Hasil: Subjek dalam penelitian ini berjumlah 57 orang. Biaya langsung Rp. 207.290.500 (rata-rata Rp. 3.636.676). Biaya tidak langsung Rp. 68.016.900 (rata-rata Rp. 1.193.300). Biaya kesakitan penyakit DBD sebesar Rp.275.307.500 (rata-rata Rp. 4.829.955). Biaya kesakitan penyakit DBD lebih tinggi pada aki-laki, kelompok >15 tahun, kelompok pekerja, lama sakit $>7$ hari, tidak memiliki jaminan kesehatan dan tidak menggunakan jaminan kesehatan, penggunaan fasilitas layanan kesehatan, praktik swasta dan
RSUD, > 2 kali kunjungan, dan waktu tempuh $>15$ menit. Hasil analisis menunjukkan umur $(p=0,0209)$, status pekerjaan $(0,0389)$, kepemilikan jaminan kesehatan (0,0022), dan penggunaan jaminan kesehatan ( $p=0,0003)$. Simpulan: Biaya kesakitan penyakit DBD adalah sebesar Rp. 275.307.500, dimana 75,29\% merupakan biaya langsung dan $24,71 \%$ biaya tidak langsung. Penelitian merekomendasikan untuk meningkatkan peran aktif semua sektor terkait dan pembagian peran yang jelas untuk setiap sektor sehingga pengendalian DBD menjadi terarah dan anggaran untuk upaya pencegahan dan pengendalian DBD.

Kata kunci: biaya; demam berdarah dengue; puskesmas; rumah sakit

\section{PUSTAKA}

1. World Health Organization. Global strategy for dengue prevention and control 2012-2020. Geneva. 2012.

2. Brady OJ, Gething PW, Bhatt S, Messina JP, Brownstein JS, Hoen AG, Moyes CL, Farlow AW, Scott TW, Hay SI. Refining the global spatial limits of dengue virus transmission by evidence-based consensus. PLoS neglected tropical diseases. 2012 Aug 7;6(8):e1760.

3. Bhatt S, Gething PW, Brady OJ, Messina JP, Farlow AW, Moyes CL, Drake JM, Brownstein JS, Hoen AG, Sankoh O, Myers MF. The global distribution and burden of dengue. Nature. 2013 Apr;496(7446):504.

4. Castañeda-Orjuela $\mathrm{C}$, Díaz $\mathrm{H}$, Alvis-Guzman $\mathrm{N}$, Olarte A, Rodriguez H, Camargo G, De la Hoz-Restrepo F. Burden of disease and economic impact of dengue and severe dengue in Colombia, 2011. Value in Health Regional Issues. 2012 Dec 1;1(2):123-8.

5. Edillo FE, Halasa YA, Largo FM, Erasmo JN, Amoin NB, Alera MT, Yoon IK, Alcantara AC, Shepard DS. Economic cost and burden of dengue in the Philippines. The American journal of tropical medicine and hygiene. 2015 Feb 4;92(2):360-6.

6. Kementerian Kesehatan. Profil Kesehatan Indonesia Tahun 2014, Jakarta: 2015.

7. Dinas Kesehatan Kabupaten Banjarnegara. Profil Kesehatan Kabupaten Banjarnegara Tahun 2010. Banjarnegara. 2011.

8. Dinas Kesehatan Kabupaten Banjarnegara. Profil Kesehatan Kabupaten Banjarnegara Tahun 2011 Banjarnegara. 2012.

9. Dinas Kesehatan Kabupaten Banjarnegara. Profil Kesehatan Kabupaten Banjarnegara Tahun 2012 Banjarnegara. 2013.

10. Dinas Kesehatan Kabupaten Banjarnegara. Laporan Mingguan dan Bulanan Kasus DBD Kabupaten Banjarnegara Tahun 2014, Banjarnegara. 2015.

11. RSUD Hj. Anna Lasmanah Banjarnegara. Data Penderita DBD yang Dirawat di RSU Banjarnegara Tahun 2012-2015, Banjarnegara. 2015. 
12. Halasa YA, Shepard DS, Zeng W. Economic cost of dengue in Puerto Rico. The American journal of tropical medicine and hygiene. 2012 May 1;86(5):745-52.

13. Lloyd LS. Best practices for dengue prevention and control in the Americas.

14. Shepard DS, Undurraga EA, Halasa YA. Economic and disease burden of dengue in Southeast Asia. PLoS neglected tropical diseases. 2013 Feb 21;7(2):e2055.

15. Tuzzahra RI. Hubungan Beberapa Parameter Hematologi dengan Lama Rawat Inap Pasien Demam Berdarah Dengue (DBD) Dewasa di Rumah Sakit Umum (RSU) Kota Tangerang Selatan Tahun 2014-2015 (Bachelor's thesis, FKIK UIN Jakarta).

16. Machado AA, Estevan AO, Sales A, da Silva Brabes KC, Croda J, Negrão FJ. Direct costs of dengue hospitalization in Brazil: public and private health care systems and use of WHO guidelines. PLoS neglected tropical diseases. 2014 Sep 4;8(9):e3104.

17. Shepard DS, Halasa YA, Tyagi BK, Adhish SV, Nandan D, Karthiga KS, Chellaswamy V, Gaba M, Arora NK, INCLEN Study Group. Economic and disease burden of dengue illness in India. The American journal of tropical medicine and hygiene. 2014 Dec 3;91(6):1235-42.

18. Undurraga EA, Betancourt-Cravioto M, Ramos-Castañeda J, Martínez-Vega R, Méndez-Galván J, Gubler DJ, Guzmán MG, Halstead SB, Harris E, Kuri-Morales P, Tapia-Conyer R. Economic and disease burden of dengue in Mexico. PLoS neglected tropical diseases. 2015 Mar 18;9(3):e0003547.

19. Gao L, Xia L, Pan SQ, Xiong T, Li SC. Burden of epilepsy: a prevalence-based cost of illness study of direct, indirect and intangible costs for epilepsy. Epilepsy research. 2015 Feb 1;110:146-56.

20. Suaya JA, Shepard DS, Siqueira JB, Martelli CT, Lum LC, Tan LH, Kongsin S, Jiamton S, Garrido F, Montoya R, Armien B. Cost of dengue cases in eight countries in the Americas and Asia: a prospective study. The American journal of tropical medicine and hygiene. 2009 May 1;80(5):846-55.
21. Triana N, Kusnanto H. Variasi Tagihan Pasien Rawat Inap Penyakit Demam Berdarah dan Appendicitis di Rumah Sakit Umum Pusat dr. Sarjito Yogyakarta (Doctoral disdantion, Universitas Gadjah Mada).

22. Magdalena Purnama S. Faktor-faktor risiko kejadian demam berdarah Dengue (DBD) dan Pemetaan Resistensi Nyamuk Aedes Aegyptu Di Kecamatan Wonogiri Kabupaten Wonogiri Tahun 2010. Universitas Gadjah Mada. 2011.

23. von Campenhausen S, Winter Y, e Silva AR, Sampaio C, Ruzicka E, Barone P, Poewe W, Guekht A, Mateus C, Pfeiffer KP, Berger K. Costs of illness and care in Parkinson's disease: an evaluation in six countries. European Neuropsychopharmacology. $2011 \quad$ Feb 1;21(2):180-91.

24. Martias I. Analisis Pemanfaatan Pelayanan Kesehatan Bagi Masyarakat Miskin Kajian Survey Sosial Ekonomi Nasional Tahun 2011. Universitas Gadjah Mada. 2013.

25. Radja II. Asuransi Kesehatan Sosial dan Biaya Out of Pocket di Indonesia Timur. Universitas Gadjah Mada.2014.

26. Praptiningsih CY, Lafond KE, Wahyuningrum Y, Storms AD, Mangiri A, Iuliano AD, Samaan G, Titaley CR, Yelda F, Kreslake J, Storey D. Healthcare-seeking behaviors for acute respiratory illness in two communities of Java, Indonesia: a cross-sectional survey. Journal of epidemiology and global health. 2016 Jun 1;6(2):77-86.

27. Burton C, McGorm K, Richardson G, Weller D, Sharpe M. Healthcare costs incurred by patients repeatedly referred to secondary medical care with medically unexplained symptoms: a cost of illness study. Journal of psychosomatic research. 2012 Mar 1;72(3):242-7.

28. Wagstaff A. The Millennium Development Goals for health: rising to the challenges. World Bank Publications; 2004. 
